\title{
TRANSLATORS AS MEDIATOR: CULTURAL NEGOTIATION IN TRANSLATING ENGLISH LITERARY TEXT INTO INDONESIAN
}

\author{
Nadia Khumairo Ma'shumah ${ }^{1}$, Aulia Addinillah Arum ${ }^{2}$, Arif Nur Syamsi ${ }^{3}$ \\ Universitas Gadjah Mada (UGM), Yogyakarta, Indonesia ${ }^{1,2}$ \\ State University of Yogyakarta (UNY), Yogyakarta, Indonesia ${ }^{3}$ \\ E-mail: nadia.khumairo@mail.ugm.ac.id
}

Received: 2021-10-06

Accepted: 2021-11-09

\begin{abstract}
This study explores the translation of cultural-specific terms in the literary text as the translation process connects cultural differences between the source and target languages. Using Eco's notion of "translation as negotiation"; Bassnett's "translators as a mediator of cultures", and Newmark's cultural categorizations of terms as the framework and this qualitative study analyzed two Indonesian versions of the novel The Secret Garden by Francess Hodgson Burnett (1911). The first translated version was published in 2010 under the title "Taman Rahasia", whereas the second translated version was published in 2020 under the same title as the original version. This study has shown the complexity in closing the cultural gap between the source text and target text. As the impact, both translators used different forms of negotiation to accommodate readers' expectations and to functionally create optimal target texts in the target culture, which differentiate into five categories (i.e., ecological, material culture; social culture, social, politic, and administrative organizations; and gestures and habits).
\end{abstract}

Keywords: translator as mediator, cultural negotiation, cultural terms

\section{Introduction}

The principle that a translation product should have an equivalence relation with the source is problematic for the translators (Hatim \& Mason, 1990; Hirako, 1999; Nababan, 2008), especially when dealing with specific-cultural terms translation. In this case, it is deemed necessary to understand that the transfer of messages in the translation process is always marked with several cultural gaps (cultural differences) between the SL and TL (Hoed, 2006) since "no language can exist unless it is steeped in the context of culture; and no culture can exist, which does not have at its center, the structure of natural language" (Bassnett, 2002). Similarly, House (2018) expresses that "language is viewed as embedded in culture such that the meaning of any bit of language can only be understood with reference to the cultural context enveloping it." As an illustration, Bester in Gao $(2016$, p.15) expresses the difficulties in translating culturally specific words, such as "a plant, a tree, or a special food," when they have "all kinds of associations" in the source text.

Nevertheless, in The Theory and Practice of Translation, Nida \& Taber (1974, p. 12) propose the concept of "dynamic equivalence," which refers to the "closest natural equivalent" to the message of the source language, first in terms of meaning and secondly in terms of style." In the same manner, Wills $(1982$, p. 3) proposes that "translation as a 
transfer process which aims at the transformation of a written SL text into an "optimally equivalent" TL text." In a nutshell, Nida \& Taber employed the term of "closest natural equivalent meaning. " In contrast, Wills employed the term of "optimally equivalent" for creating functionally optimal target texts in the target culture since they realized that full (absolute) equivalence sometimes cannot be fully maintained and achieved in translation. These terms are slightly important as there are three main reasons the "sameness" is challenging to achieve (Hervey, Higgins \& Haywood in Nababan, 2008). First, a text cannot have constant interpretations even for the same person on two occasions. Second, translation is a matter of the translator's subjective interpretation. Third, it seems impossible for translators to determine readers' or audiences' responses when first produced. Because of that, equivalence, then, was transformed into creative and situational (Cronin, 2003, pp. 24-25) rather than static and binary (Catford, 1965). Then, the negotiation term in translation arose, focusing on the translator's decisions (Eco, 2003).

Relating to its transformation, Bassnett (2002) proposes today, translation is understood as a process of negotiation between texts and culture in which all types of transactions occur mediated by the translator figure. The "negotiation" is a complex process in which the translator will have to make several (often competing) decisions (Bellos, Eco \& Watt in Redelinghuys, 2019, p. 825). The consequence of this role is that translators must understand cultural differences as a kind of negotiation (Aich, 2021, p. 81), as the translation of cultural terms may change from time to time depending on the situations and contexts. Thus, the symptoms of omission and betrayal may occur for creating successful crosscultural communication (Bassnett, 2002; Bedeker \& Feinauer, 2006; Sajarwa, 2017).

Centered on the background of the study, this research endeavors to investigate (1) the variety of cultural-specific terms found in the novel and its two translated versions; and (2) translator decisions in negotiating the translation of cultural-specific terms from English into Indonesian. Since Saule \& Aisulu (2014) claimed that cultural differences affect the way people perceive text and allow some modifications from ST to TT, this research would be advantageous for translators and researchers in providing the fundamental tool and new perspective for examining translation processes in literary works by considering the fact that every reader of literary works (including translators themselves) has the flexibility and freedom in translating and understanding the texts. They will not concretize only one meaning but let all possible meanings alive along with their interpretation (Junus, 1985).

\section{Literature Review}

\subsection{Cultural Terms}

Since Newmark (1988, p. 95) proposed that language becomes a natural phenomenon embedded in cultural features, many researchers have realized the importance of culturalspecific terms in translation. As a result, studies on cultural terms in translation have been primarily investigated. Specific on cultural categorizations, by adapting Nida's theory, Newmark (1988, pp. 95-96) divided cultural terms into (1) ecology, which belongs to specific ecological features such as animals, plants, local winds, mountains, plains; (2) material culture (artifacts) which belong to culture-specific elements, such as foods, clothes, housing, transportations, tools, and equipment; (3) social culture (work and leisure) such as the names of occupations, music, games or dances; (4) organizations, customs, activities, procedures, concepts such as political, social, legal, religious and artistic terms; and (5) gestures and habits. 
In Indonesia, Purnomo and Baharuddin (2018) conducted an investigation-based study on a novel translation product translated from English into Bahasa Indonesia. They believe that specific terms concerning geographic names and expressions of different cultures often give difficulties to translators of literary works, especially in novels. Through Purnomo and Baharuddin's evaluation, it can be seen that translation strategies suggested by several experts may overlap. When applying Nida's componential analysis, some cultural terms might fail to be translated. Nevertheless, the translation is successfully rendered using Vinay and Darbelnet procedures, Bassnett's cultural translation principle, Hatim's clarity, Larson's meaning-based, and Newmark's classification.

Although overall findings showed that the use of several strategies in translation was still debatable when applied to the translation from ST to TT, we saw that the translation strategy is not the only problem when facing two different translation products. More than that, translation negotiation emerges as a way of looking at translation from a different perspective and point of view by focusing on translation as a translating process, the translator's role as the mediator, and translation as the product by focusing on some decisions.

\subsection{Cultural Negotiation}

Translating a text, either literary or non-literary, is always concerned with culture. Consequently, the translation process will always involve adjustments, changes, agreements, and cultural activities that influence a translator's decision. Such a translation process is called a negotiation in translation. The rendering of the message, consisting of words and grammatical structures, is of utmost importance (Hatim, 2005) in the negotiating process of translation. Translators play the role of mediators who can negotiate a place or space between SL and TL space and culture. The 'between' position becomes an influential and elusive place for a writer to fill.

The studies of negotiation in translation spread around the world and were implemented in some languages. Siponkonski (2014) examines The Textual Interplay of Translators and Editors in Contemporary Finnish Shakespeare Translation by considering the translation process and product. The primary material entails the manuscripts of four contemporary Finnish translations of Shakespeare's tragedies and the final editions of these plays published between 2004 and 2009. The findings suggest that the established translators have more power in the negotiations than the non-established translators, and their voice is more substantial than the editors'. Based on the external factor, Haliloglu in Dow (2007) investigates cultural negotiation in the case of Fatma Aliye in the Tanzimat period in Turkey. She found that cultural negotiation within translation becomes essential, mainly when a culture absorbs foreign cultural norms.

Translation products rely on the concept of translation ideology used in translation as part of the negotiation. They examine the negotiation in The Gift of Magi into Pemberian Sang Majus. The data is qualitatively analyzed in this research. Generally, it can be concluded that the negotiation of cultural translation is preferably oriented to source language culture by applying a foreignization strategy. Apart from classic discussion of ideology, Sajarwa (2017) used the concept of negotiation in translation to investigate the deconstruction of equivalence by focusing on different translation versions of a French text translated into Indonesian. He found that differences in TT1 and TT2 are the results of the translators' inventive ability, creativity, intuition, and experience and knowledge. The 
Translators as Mediator: Cultural Negotiation in Translating English Literary Text into Indonesian, Nadia Khumairo Ma'shumah, Aulia Addinillah Arum, Arif Nur Syamsi

difference in the translation of the ST into TT1 and TT2 indicates a change towards strengthening national identity.

The studies mentioned earlier have implied that negotiation in translation theory can reveal various things from various perspectives. Nonetheless, there is always room for the development of translation negotiation research as there are still many translation negotiations that have not been disclosed, especially when facing the problem of the translation of cultural terms.

\section{Research Method}

The data of this research are narrative and textual discourses of (1) an English novel, The Secret Garden, written by Francess Hodgson Burnett (1911) as the Source Text (consists of 27 chapters with 343 pages) published in 2019 by PT. Gramedia Pustaka Utama; (2) Indonesian translation of The Secret Garden "Taman Rahasia" by Barokah Ruziati as the Target Text 1 (consists of 27 chapters with 320 pages) published in 2010 by PT. Gramedia Pustaka Utama and (3) Indonesian translation of The Secret Garden by Airien Kusumawardani as the Target Text 2 (consists of 27 chapters with 312 pages) published in 2020 by PT. Elex Media Komputindo. The selection of the novel and its translated versions as data sources or material objects of this study were based on two considerations. First, The Secret Garden as the source text was tightly packed with cultural terms, using Indian and Yorkshire as the story's settings. Second, regarding translators' competencies, Barokah Ruziati, as a TT1 translator, was a professional translator in Himpunan Penerjemah Indonesia (Association of Indonesian Translators) since 2012. In contrast, Airien Kusumawardani was a freelance translator since 2010, specializing in fiction books with 30 distinct works published by several local publishing companies. Different translator backgrounds are suspected as one of the essential aspects contributing to both translation products' lexical choices. Since The Secret Garden, written by Frances Hodgson Burnett, was initially published as a serial story in The American Magazine in 1910, it was claimed to be one of the most popular children's books in 1911. Beginning the story in India, the novel has served the readers with the adventure story of Marry Lennox to Misselthwaite Manor after a cholera epidemic kills her parents and all her servants. All-natural settings are rich in a specific culture and educate the readers with new experiences and knowledge.

As the hallmark, this research applied comparative methods by comparing the existing ST with TT1 and TT2. The data were taken, observed, and collected using documentation techniques through content analysis methods in the form of words and phrases containing different cultural terms served in Indonesian translation, both TT1, and TT2. This research was data-driven. The data, in the form of words or phrases, were analyzed in this research. This research applied a descriptive-qualitative method for in-depth analysis by applying textual analysis, which produces narrative or textual descriptions of the existing phenomena under the research (Vanderstoep and Johnston, 2009, p. 167). Hence, theoretical and methodological triangulation techniques were employed to achieve credibility, dependability, transferability, and confirmability by implying multiple theories and applying appropriate methodologies during collecting and analyzing the data.

\section{Results and Discussion}

Focusing on the translation product, the translation of cultural terms and negotiations as part of translators' decisions found in this research is quite diverse and widespread. In these findings and discussion section, specific-cultural-terms classifications, translation 
differences in translating cultural-specific-terms, and translator's decisions in translating cultural-specific-terms were correlated and cannot be separated. Nevertheless, since there is no standard for translating cultural terms affected by a cultural gap, it perpetuates the translation process. The choice of words becomes subjective and changeable due to translators' different perceptions, knowledge, and decision-making; so that, the differences between the translation of cultural terms from ST into TT1 and TT2 as shown below.

\subsection{The variety of ecological terms found in the ST and its two translated versions}

\section{Excerpt 1}

ST : "No, not it," answered Mrs. Medlock. "Nor it isn't fields nor mountains, it's just miles and miles and miles of wild land that nothing but heather and gorse and broom, and nothing lives on but wild ponies and sheep." (SG,1911/2019: 30)

TT1 : "Bukan, bukan laut," sahut Mrs. Medlock. "Juga bukan ladang atau pegunungan, hanya bermil-mil tanah liar yang tak bisa ditumbuhi tanaman apa pun selain semak heather dan gorse dan broom, dan tidak ada hewan yang bisa hidup dari semak-semak itu selain kuda poni liar dan domba." (TR, 2010: 26)

TT2 : "Bukan, ini bukan laut," sahut Mrs. Medlock. "Ini juga bukan padang rumput atau pegunungan, hanya tanah liar seluas bermil-mil di mana tidak ada apapun yang tumbuh selain semak berbunga heather ${ }^{3}$, gorse ${ }^{4}$, dan broom ${ }^{5}$. Tidak ada yang menghuni padang ini kecuali kuda poni dan domba liar."

${ }^{3}$ Semak berbunga ungu-merah muda, sesekali putih, yang termasuk ke dalam tanaman yang berdaun dan berbunga hampir sepanjang tahun dan lebah yang menghisap sarinya dapat menghasilkan madu heather yang bercita rasa kuat dengan tekstur seperti agar-agar.

${ }^{4}$ Salah satu jenis tanaman yang menghasilkan bunga berwarna kuning, termasuk tanaman hijau abadi yaitu yang selalu berdaun hijau apapun musimnya.

${ }^{5}$ Semak berbunga kuning yang dapat tumbuh hingga sekitar 1-3 meter, bisa tumbuh di tanah kering atau berpasir dan mampu bertahan sampai suhu sekitar -25 derajat Celcius. (SG, 2020: 23)

Identified from the motives, the difference between TT1 and TT2 above lies in linguistic factors. It can be seen when a translator decided to translate "heather and gorse and broom" into "semak heather dan gorse dan broom," it means that translator 1 saw ST as a whole plant by looking at them as shrubbery. Meanwhile, when a translator translated ST into "semak berbunga heather, gorse, dan broom" by using translation notes, the translator perceived ST as part of the shrubbery since it has many parts including the leaves, stems, flowers, and roots.

\section{Excerpt 2}

ST : :...It smells o' honey an' broom an' there's such a lot o' fresh air -- an' th' sky looks so high an' th' bees an' skylarks make such a nice noise hummin'an' singin'." (SG, 1911/2019: 35) 
Translators as Mediator: Cultural Negotiation in Translating English Literary Text into Indonesian, Nadia Khumairo Ma'shumah, Aulia Addinillah Arum, Arif Nur Syamsi

TT1 : "...Sewangi madu dan begitu banyak udara segar -- langit terlihat sangat tinggi, lebah dan burung pekicau bersuara riang, berdengung dan bernyanyi." (TR, 2010: 30)

TT2 : "...Wanginya seperti madu dan udara di sana segar sekali-- langit tampak menjulang, lebah dan burung skylark mengeluarkan suara berdengung dan kicauan yang merdu sekali." (SG, 2020: 27)

\section{Excerpt 3}

ST $\quad:$...She went to her walk outside the long, ivy-covered wall over which she could see the tree-tops. (SG,1911/2019: 80)

TT1 : ...Dia pergi ke jalan di luar dinding panjang berselimut ivy yang dari atasnya dia bisa melihat puncak-puncak pohon. (TR,2010: 73)

TT2 : ...Gadis itu menyusuri jalan setapak berselimutkan tanaman merambat, tempat dia bisa melihat puncak pepohonan. (SG, 2020: 68)

Previous excerpts closer inspection reveals that the difference between TT1 and TT2 in excerpts (2) and (3) was related to different ideologies. In excerpt (2) above, the word 'skylark' was translated into 'burung pekicau [chirping bird]' in TT1 and 'burung skylark' in TT2. Meanwhile, the word 'ivy' in excerpt (3) was translated into 'ivy' in TT1 and 'tanaman merambat' in TT2. Unfortunately, referring 'skylark' into 'burung pekicau [chirping bird]' as generalization became a problem in translation. It has many endemic references as there are many kinds of 'burung pekicau [chirping bird]' in Indonesia, such as 'murai, kenari, panca warna, kolibri, gelatik, ' and so on or 'sparrow, cuckoo, thrush, canary, robin,' and so on. The idea of implementing domestication ideology may be understood as an attempt to overcome as many language barriers as possible and to expand the outreach of a literary work in the target culture. Nevertheless, although the findings show that domestication makes the translation more readable, domestication ideology in the form of generalization words in this translation can obscure the essence of cultural elements manifested in the source text. The phenomenon happens because Skylarks (Alauda Arvensis) are species of small passerine birds. They breed throughout most of Europe and Asia and in northern Africa's mountains (see www.cs.mcgill.ca). In the same case, as mentioned in excerpt (3), the word 'ivy' was translated into 'ivy' in TT1 (using the ideology of foreignization) and 'tanaman merambat [vines]' in TT2 (using the ideology of domestication). However, there are many species of 'tanaman merambat [vines]' worldwide since it was presumed to be the closest meaning that could be achieved. Nonetheless, both findings showed translators' inconsistency when applying both ideologies in translation work, although combining ideology is commonly applied in translation.

\subsection{The variety of material culture found in the ST and its two translated versions}

\section{Excerpt 4}

ST : The Ayah had been taken ill in the night, and it was because she had just died that the servants had wailed in the huts. (SG, 1911/2019: 10-11)

TT1 : Ayah Mary jatuh sakit pada malam sebelumnya, dan para pelayan meratap di gubuk mereka karena perempuan itu baru saja meninggal dunia. (TR, 2010: 5)

TT2 : Ayah-nya jatuh sakit malam sebelumnya, dan para pelayan meratap di pondok-pondok karena dia baru saja meninggal dunia. (SG, 2020: 8) 


\section{Excerpt 5}

ST : "No, not it," answered Mrs. Medlock. "Nor it isn't fields nor mountains, it's just miles and miles and miles of wild land that nothing but heather and gorse and broom, and nothing lives on but wild ponies and sheep." (SG, 1911/2019: 30)

TT1 : "Bukan, bukan laut," sahut Mrs. Medlock. "Juga bukan ladang atau pegunungan, hanya bermil-mil tanah liar yang tak bisa ditumbuhi tanaman apa pun selain semak heather dan gorse dan broom, dan tidak ada hewan yang bisa hidup dari semak-semak itu selain kuda poni liar dan domba." (TR, 2010: 26)

TT2 : "Bukan, ini bukan laut," sahut Mrs. Medlock. "Ini juga bukan padang rumput atau pegunungan, hanya tanah liar seluas bermil-mil di mana tidak ada apapun yang tumbuh selain semak berbunga heather ${ }^{3}$, gorse ${ }^{4}$, dan broom ${ }^{5}$.

Tidak ada yang menghuni padang ini kecuali kuda poni dan domba liar."

3Semak berbunga ungu-merah muda, sesekali putih, yang termasuk ke dalam tanaman yang berdaun dan berbunga hampir sepanjang tahun dan lebah yang menghisap sarinya dapat menghasilkan madu heather yang bercita rasa kuat dengan tekstur seperti agar-agar.

${ }^{4}$ Salah satu jenis tanaman yang menghasilkan bunga berwarna kuning, termasuk tanaman hijau abadi yaitu yang selalu berdaun hijau apapun musimnya.

${ }^{5}$ Semak berbunga kuning yang dapat tumbuh hingga sekitar 1-3 meter, bisa tumbuh di tanah kering atau berpasir dan mampu bertahan sampai suhu sekitar -25 derajat Celcius. (SG, 2020: 23)

In excerpt (4), the ST 'huts' was translated into 'gubuk' in TT1 and 'pondok' in TT2. Although the words' gubug' and 'pondok' have similar meanings as two synonymous words, they are not identical because they have different forms. The word 'gubuk' usually refers to a temporary building, whereas 'pondok' usually refers to a more permanent one. In addition, the lexical meaning of 'gubuk' contains a connotation that is often associated with poverty, whereas the word 'pondok' does not have any connotative meaning. From this sample, we can assume that the decision of translator 1 in using the word 'gubuk' is motivated by the urgency to emphasize the character's social background in the novel (Mary's servants). Meanwhile, in excerpt (5), the ST' field' was translated into 'ladang' in TT1 and 'padang rumput [meadow]' in TT2. It is interesting to see that both translators have used two words with different lexical meanings. The word 'ladang' as material culture was frequently referred to agricultural land managed by people [+land; +agriculture; +grazing]. The word 'padang rumput [meadow]' was frequently used to refer to an open habitat or a wild area vegetated by grasses, herbs, and other non-woody plants [+land; -agriculture; +grazing]. In line with what Cahyono (1995) has said, synonyms can be interpreted as two or more words with similar meaning or almost the same but cannot always replace each other in the sentence structure. Consequently, the form is easily transposable, but the meaning is complex.

\section{Excerpt 6}

ST : The woman was his housekeeper at Misselthwaite Manor, and her name was Mrs. Medlock. She was a stout woman, with very red cheeks and sharp black eyes. She wore a very purple dress, a black silk mantle with jet fringe on it 
Translators as Mediator: Cultural Negotiation in Translating English Literary Text into Indonesian, Nadia Khumairo Ma'shumah, Aulia Addinillah Arum, Arif Nur Syamsi

and a black bonnet with purple velvet flowers which stuck up and trembled when she moved her head. (SG, 1911/2019: 19)

TT1 : Wanita itu pengurus rumah di Misselthwaite Manor, namanya Mrs. Medlock. Dia wanita yang gagah, dengan pipi sangat merah dan mata hitam tajam. Dia mengenakan gaun yang sangat ungu, mantel sutra hitam dengan pinggiran berhias batu jet, dan topi hitam dengan bunga-bunga beludru ungu yang mencuat dan bergetar saat ia menggerakkan kepala. (TR, 2010: 15-16)

TT2: Wanita itu pengurus rumah Mr, Craven di Misselthwaite Manor, dan namanya adalah Mrs. Medlock. Sang pengurus rumah adalah seorang perempuan gempal, dengan pipi sangat merah dan mata hitam yang tajam. Dia memakai gaun ungu terang, mantel sutra hitam berhiaskan rumbai hitam gelap dan topi bonnet hitam dengan bunga-bunga beledu ungu yang mencuat dan bergetar saat dia menggerakkan kepalanya. (SG, 2020: 13-14)

In contrast with previous findings, in excerpt (6), there were different perceptions and interpretations in translating 'jet fringe' and 'a black bonnet.' The phrase 'purple velvet flowers' was translated with the same perceptions but different spelling. The phrase 'jet fringe' was translated into 'batu jet' in TT1 and 'rumbai hitam gelap' in TT2 since there was no reference to 'jet fridge' in Indonesian. It means that there was a different perspective from both TT1 and TT2's translators. TT1's translator defines 'jet fridge' as a kind of stone, while TT2's translator refers to a kind of tassel. It was clear that stone and tassel are two different things; this shows the translator's presumption in perceiving a specific cultural term. On the other hand, the phrase 'black bonnet' was translated into 'topi hitam' in TT1 and 'topi bonnet hitam' in TT2. It should be noted that TT1 translators used generalization to transfer the phrase 'black bonnet into a general headgear. Meanwhile, TT2 translators kept the cultural bound by maintaining the word 'bonnet' to mention a specific type of headgear. Interestingly, 'purple velvet flowers' were translated into 'bunga-bunga beludru ungu' in TT1 and 'bunga-bunga beledu ungu' in TT2 due to different lexical choices since 'beledu' and 'beludru' are two synonymous and identical words. Unfortunately, the word 'beledu' was rarely used by present Indonesian native speakers. As the impact, the word 'beludru' may be more acceptable for present Indonesian readers.

\section{Excerpt 7}

ST : Across The Moor. (SG, 1911/2019: 27)

TT1 : Di Padang Moor. (TR, 2010: 23)

TT2 : Di Seberang Padang Belantara. (SG, 2020: 20)

In excerpt (7), the translator in TT1 interpreted 'Moor' as the name of a place. Meanwhile, the translator in TT2 identified 'moor' as 'padang belantara.' This finding showed that translators' different perceptions and interpretations would have impacts on translators' decisions. There are two possible causes behind the translation of TT1. The first cause is that the translator assumed that Moor was a proper name that could not be translated. The second possible cause is that the translator assumes that Moor is an adjective that does not have an equivalent translation in Indonesia, and thus he kept it as it is. Nevertheless, we argue that, in this case, the different translations will not have a significant impact on readers' comprehension since the focus of the phrase 'Padang Moor' 
and 'Padang belantara' lies on the noun (padang) and not on the adjective (either Moor or belantara).

\section{Excerpt 8}

ST : While the secret garden was coming alive and two children were coming alive with it, there was a man wandering about certain far-away beautiful places in the Norwegian fjords and the valleys and mountains of Switzerland... (SG, 1911/2019: 325)

TT1 : Sementara taman rahasia menjadi hidup dan dua anak ikut hidup bersamanya, seorang pria menjelajahi tempat-tempat indah nun jauh di teluk-teluk curam Norwegia dan lembah serta pegunungan Swiss. (TR, 2010: 304)

TT2 : Sementara taman rahasia mulai hidup dan dua anak mulai hidup bersamanya, ada seorang lelaki yang menjelajahi tempat indah nun jauh di sekitar fyord ${ }^{13}$ Norwegia serta lembah dan pegunungan Swiss.

${ }^{13}$ Teluk yang berasal dari lelehan gletser, biasa ditemukan di Skandinavia dan Amerika Utara. (SG, 2020: 296)

Based on the TT1 and TT2, we can infer that both translators have adopted different strategies caused by the time gap, which is almost one decade long (TT1 published in 2010 and TT2 published in 2020). Before explaining the different strategies, we would like to highlight that the word 'Fjord' has no equivalent meaning in Indonesian due to different characteristics of Southeast Asian and Scandinavian geography. 'Fjords' are described and defined as a natural phenomenon that was created by glaciers. A 'fjord' is a long, deep, narrow body of water that reaches far inland. 'Fjords' are often set in a U-shaped valley with steep walls of rock on either side (see https://www.nationalgeographic.org/encyclopedia/fjord/). This case exemplifies what Baker (2018) has introduced as problems of non-equivalence due to the absence of the lexicalized concept of the source language in the target language.

To overcome this issue, the translator of TT1 decided to apply a paraphrasing strategy with the unrelated word (Baker, 2018). In this case, the translator unpacked the meaning of the word 'fjord' by using a superordinate lexical ('teluk-teluk') which resembles the form and shape of 'fjords' and add an adjective ('curam') to trigger the imagination of the readers. According to Baker (2018), professional translators often apply this strategy if the word in question is semantically complex. Meanwhile, translator 2 adopted the loan word strategy with additional notes. Given that the TT2 was published in 2020, the loan word of 'fjord,' or written as 'fyord' in Indonesian, has been widely accepted in Indonesia. Based on a simple Google search, 'fyord' has been included in various writings in Indonesian.

\section{Excerpt 9}

ST : Just as he was goin' away our 'Lizabeth Ellen called out, 'Mother, he's got skippin' ropes with red an' blue gandles.' An' mother she calls out quite sudden, 'Here, stop, mister! How much are they?' An' he says Tuppence', an' mother she began fumblin' in her pocket an' she says to me, 'Martha. Tha's brought me thy wages like a good lass, an' I've got four places to put every penny, but I'm just goin' to take tuppence out of it to buy that child a skippin'-rope,' an' she bought one an' here it is. (SG, 1911/2019: 87) 
TT1 : Baru saja dia berjalan lagi 'Lizabeth Ellen kami berteriak, 'Ibu, dia punya tali lompat dengan pegangan merah dan biru.' Dan lbu tiba-tiba memanggil orang itu, 'Hei, berhenti sebentar, Mister! Berapa harganya?' Orang itu menjawab, 'Dua sen,' lalu Ibu mulai merogoh-rogoh sakunya dan bermurah hati, dan aku punya empat tempat untuk menyimpan setiap sen, tapi aku hanya akan mengambil dua sen dari pemberian untuk membeli tali lompat buat anak itu,' lalu Ibu membeli satu dan ini talinya. (TR, 2010: 79)

TT2 : Ketika lelaki itu akan pergi 'Lizabeth Ellen berseru, 'Ibu, dia membawa lompat tali berpegangan merah dan biru.' Dan tiba-tiba Ibu berseru, 'Tuan, berhenti! Berapa harga tali itu?' Lelaki itu bilang 'Dua pence,' dan ibu mulai merogoh sakunya lalu bilang padaku, 'Martha, jadilah gadis yang baik dan bawakan upahmu untukku. Aku punya rencana untuk setiap penny-nya, tapi aku hanya akan mengeluarkan dua pence dan membeli lompat tali untuk anak itu.' Lalu ibu membelinya dan ini dia. (SG, 2020: 75)

In excerpt (9), it was seen that there was a different cultural background between translators 1 and 2. 'Tuppence' was translated into 'dua sen' in TT1 and 'dua pence' in TT2. Meanwhile, the word 'every penny' was translated into 'setiap sen' in TT1 and' setiap penny$n y a^{\prime}$ in TT2. According to Merriam-Webster, Tuppence is a variant of twopence, which means the sum of two pennies (Merriam-Webster, 2021). Penny itself is the singular form of pence where 100 pence is 1 pound in the context of the UK currency (https://www.milesfaster.co.uk/information/uk-currency.html) Therefore, it could be seen in TT2 that it maintained a cultural bond while maintaining the form of the UK currency. In contrast to TT1, which used the term generalization by changing the culture of the UK currency into a general currency. According to Merriam-Webster, the term cent itself is a monetary unit equal to $1 / 100$ of a basic unit of value such as the dollar, euro, or rand (Merriam-Webster, 2021)

\section{Excerpt 10}

ST : Her mother had been glad to see her and they had got the baking and washing all out of the way. She had even made each of the children a doughcake with a bit of brown sugar in it. (SG, 1911/2019: 85)

TT1 : Ibunya senang melihatnya dan mereka berdua menyelesaikan tugas memanggang dan mencuci. Dia bahkan membuat kue yang ditambah sedikit gula palem untuk masing- masing anak. (TR, 2010: 77)

TT2 : Ibunya sangat senang bertemu dengannya dan mereka berdua menyelesaikan pekerjaan memanggang dan mencuci. Martha bahkan membuatkan kue panggang dengan sedikit gula cokelat di dalamnya untuk masing-masing adiknya. (SG, 2020: 73)

According to the website that provides information on traditional English food, dough cake is often called Dorset Dough Cake, a traditional English cake made with yeast (see http://www.foodsofengland.co.uk). Thus, the pre-cooked form is similar to bread's dough instead of cake's batter. Dough cake is an English-specific term that has no equivalent lexical in Indonesian. In order to prevail over the difficulty in translating culture-specific terms, the two translators used the superordinate lexical of the target language, i.e., 'kue' (cake in English). However, translator 2 also added another element, i.e., 'panggang' (baked) as the collocate of 'kue.' By adding the word 'panggang, ' translator 2 tried to, at least, provide the 
information to the readers about the process of making a Dough Cake. Therefore, the readers can have a more specific image of how a Dough Cake looks.

Both translators also used different lexical when translating brown sugar. Translator 1 translated it into 'gula palem' (palm sugar), and translator 2 translated it into 'gula coklat' (brown sugar). Again, a long-time gap is suspected to be the primary cause of this difference. Nevertheless, before we explain how the different translations are done, we also need to explain that 'palm sugar' and 'brown sugar' are two different ingredients for baking or cooking. However, the texture of both ingredients is very similar. 'Palm sugar' is a type of sweetener made of the sap of palm trees, while 'brown sugar' is made of a mixture of white sugar and molasses. Both white sugar and molasses are made of sugarcane extract. However, we should remember that Indonesian households rarely use 'brown sugar' in their cooking, given that Western cuisine influences such ingredients. Instead, we use a lot of 'palm sugar' or 'coconut sugar' in our food, and it is one of the staple food ingredients in South East Asian cuisines. Palm sugar is the granulated version of 'gula merah' (red sugar in Indonesian) or 'gula melaka' (Malakan's sugar in Malaysian dialect).

Translator one decided to translate 'brown sugar' into 'gula palem' (palm sugar), which deviated from its lexical meaning. However, this decision is understandable given that Indonesian readers were not yet familiar with the term 'gula cokelat' (brown sugar). Therefore, the translator uses 'palm sugar' due to the similarity of the form and taste profile between 'palm sugar' and 'brown sugar.' Meanwhile, translator 2 translated 'brown sugar' into 'gula cokelat,' representing the literal translation of 'brown sugar.' Gula cokelat can now be found in numerous writings, and it referred to the actual 'brown sugar' (not the 'palm sugar,' which is often mistakenly understood as 'brown sugar'). This kind of language evolution has also shown the influence of western cuisine, which Indonesians have gradually accepted.

\subsection{The variety of social cultures found in the ST and its two translated versions}

\section{Excerpt 11}

ST : She had not wanted a little girl at all, and when Mary was born, she handed her over to the care of an Ayah, who was made to understand that if she wished to please the Mam Sahib she must keep the child out of sight as much as possible. (SG, 1911/2019: 7)

TT1 : Dia sama sekali tidak menginginkan putro kecil, dan ketika Mary lahir dia menyerahkan anak itu dalam perawatan seorang Ayah, yang diberi pengertian bahwa jika ingin menyenangkan hati Mem Sahib, majikannya, sebisa mungkin dia harus menjauhkan anak itu dari Mem Sahib. (TR, 2010: 56)

TT2 : Ibu Mary sama sekali tidak pernah menginginkan seorang gadis kecil, dan ketika Mary lahir, ibunya menyerahkan Mary untuk diurus seorang Ayah, yang diberi instruksi tegas bahwa jika wanita itu ingin menyenangkan sang Mem Sahib ${ }^{2}$ dia harus memastikan gadis itu tak terlihat sebisa mungkin.

${ }^{2}$ Mem Sahib: perempuan asing berkulit putih dan berstatus sosial tinggi yang tinggal di India, khususnya istri pejabat Inggris. (SG, 2020: 2-3)

\section{Excerpt 12}

ST $\quad$ : Mistress Mary Quite Contrary. (SG, 1911/2019: 15) 
Translators as Mediator: Cultural Negotiation in Translating English Literary Text into Indonesian, Nadia Khumairo Ma'shumah, Aulia Addinillah Arum, Arif Nur Syamsi

TT1 : Mistress Mary yang Keras Kepala. (TR, 2010: 12)

TT2 : Nona Mary Si Pembangkang. (SG, 2020: 10)

Take a look at excerpts (11) and (12). We found that TT1 tends to maintain social statuses or titles from ST, while TT2 prefers to translate them into TT / Indonesian culture. In excerpts (11) and (12) above, the title 'Mem Sahib' (11) and 'Mistress' (12) were resisted in TT1 since the word 'Mistress' refers to a woman who employs or supervises servants in the Anglo-Saxon era. However, translator 2 was translated into 'Mem Sahib' (11), 'Mem Sahib' using translation notes, and 'Mistress' (12) into 'Nona' using naturalization with target language-oriented.

\subsection{The variety of social, political, and administrative organizations found in the ST and its two translated versions}

\section{Excerpt 13}

ST : "Tha' might sing th' Doxology." (SG, 1911/2019: 313)
TT1 : "Kau bisa menyanyikan Kidung Pujian itu." (TR, 2010: 293)
TT2 : "Kau bisa menyanyikan Doksologi10."
${ }^{10}$ Himne pendek yang digunakan di berbagai kebaktian Kristen, sering dinyanyikan
pada akhir kebaktian. (SG, 2020: 285)

In excerpt 13, we have found Doxology as a culture-specific term derived from Christian worship. Translator 1 has chosen to translate it into Indonesian fully. In contrast, Translator 2 has decided to use the strategy of loan words and add a footnote to describe the lexical meaning of such loan words. 'Kidung Pujian' has been known as a general term used by Christians in Indonesia, and it is known not only by the Christians themselves but also people of other religions. However, the word Doxology is only understood by Indonesian Christians. Therefore, if this novel is intended to be read by people across religions, it is necessary to provide a detailed description. Both versions, neither faithful translation nor free translation using loan words, which is called a classic debate in translation, have conveyed the original author's intended sense and meaning. In this case, the word Doxology written in ST carries no evaluative meaning nor connotation. Hence, different strategies or translation decisions did not result in any less meaningful outcome.

\subsection{The variety of gestures and habits found in the ST and its two translated versions}

\section{Excerpt 14}

ST : The woman was his housekeeper at Misselthwaite Manor, and her name was Mrs. Medlock. She was a stout woman, with very red cheeks and sharp black eyes. (SG, 1911/2019: 19)

TT1 : Wanita itu pengurus rumah di Misselthwaite Manor, namanya Mrs. Medlock. Dia wanita yang gagah, dengan pipi sangat merah dan mata hitam tajam. (TR, 2010: 15-16)

TT2 : Wanita itu pengurus rumah Mr, Craven di Misselthwaite Manor, dan namanya adalah Mrs. Medlock. Sang pengurus rumah adalah seorang perempuan gempal, dengan pipi sangat merah dan mata hitam yang tajam. (SG, 2020: 13) 
In excerpt 14, the nominal phrase a stout woman is translated differently by translator 1 and translator 2: 'wanita yang gagah' (translator 1) and 'perempuan gempal '(translator 2). First of all, the word 'wanita' and 'perempuan' are synonymous and thus does not affect the readers' comprehension. Nonetheless, we should notice that 'gagah' and 'gempal have two different lexical meanings and carry different connotations. 'Gagah' in Bahasa Indonesia means strong characteristics both personally and physically. On the other hand, 'gempal' is a pejorative word synonymous with fat or chubby. In some contexts, 'gempal' also carries a negative connotation or derogatory meaning. However, according to Oxford Learners' Dictionary (OxfordLearnersDictionaries.com, 2021) and Collins Dictionary (Collins English Dictionary, 2021), stout can mean rather fat or plump if used to describe a person's physical appearance. It also means strong if used to describe the character of an inanimate object.

Nevertheless, stout also means strong or determined if used to describe someone's actions, attitudes, beliefs, or personality. In order to clarify which translation is the closest one to the original meaning, a thorough examination of the character throughout the story must be done as the word stout itself will be manifested in the scenes or interactions with other characters. When viewed from the parallel arrangement of Mrs. Medlock on the third characteristic, namely 'sharp black eyes,' it can be concluded that the depiction of the character that ST wants to convey in the series of characters mentioned is a great figure. Parallel mention in linguistic rules when using the word 'and' in form and connotation must be of the same type. Therefore, a description closer to what ST means is the result of translator 1 , which has a positive connotation.

\section{Excerpt 15}

ST : "A more marred-looking young one I never saw in my life,' Mrs. Medlock thought. (Marred is a Yorkshire word and means spoiled and pettish). (SG, 1911/2019: 21)

TT1 : "Aku tak pernah melihat anak semanja dan sepemarah ini seumur hidupku," pikir Mrs.Medlock. (TR, 2010: 18)

TT2 : "Dia anak paling rusak yang pernah kulihat seumur hidupku," pikir Mrs. Medlock. (rusak adalah kata dalam dialek Yorkshire yang berarti manja dan berperangai buruk). (SG, 2020: 16)

The ST in excerpt 15 is completed with a further description of the phrase 'marredlooking' by the author. This was done due to the word's specific use in a particular region, i.e., Yorkshire. According to the additional note by the author, Marred is a Yorkshire word that means spoiled and pettish. However, in the Oxford Learners' Dictionary, Mar is featured as one entry which means "to damage something or make something less good or successful." The different meanings are eventually reflected in the translation strategy by the two translators. However, before we elaborate on the differences between the translations, we can infer the author's intended meaning from her description, i.e., to describe that the character is a spoiled and pettish child.

Therefore, the TT1 has achieved the closest equivalence with the translation that refers to the descriptions given by the author, rather than just referring to the lexical meaning of the word Marred-looking/Mar in the dictionary. This decision has also resulted in the omission of the footnote. Meanwhile, TT2 has adopted the lexical meaning of Marred, which means ruined, damaged, or rusak, in Indonesian and provided the literal translation of the footnote. This might have led to confusion among readers since the translator wrote 'rusak' 
Translators as Mediator: Cultural Negotiation in Translating English Literary Text into Indonesian, Nadia Khumairo Ma'shumah, Aulia Addinillah Arum, Arif Nur Syamsi

is a word in Yorkshire dialect which means spoiled and pettish" as the translation of the footnote. The translator tried to persuade the readers to think that the word 'rusak' was a Yorkshire word.

However, there are some losses of meaning resulting from the two translations. The omission of the footnote has made the dialect of Yorkshire becomes unrecognized. On the other hand, the word 'rusak' in Indonesian does not have any similar meaning to 'spoiled' and 'pettish.' The deviation of meaning may be deemed intolerable to some knowledgeable reader, given that 'rusak' can carry different evaluative meaning although the three words, 'rusak' (ruined), 'manja' [spoiled] and 'pemarah' [pettish] also loaded with negative connotations.

\section{Conclusion}

The findings in our study have added clear evidence that perfect translation (fully equivalence) of cultural terms is a utopian expectation of the target text readers due to the gap between the source language culture and target language culture. In order to accommodate readers' expectations while preserving the meaning intended by the original author, a translator must play the role of a mediator who negotiates conveying messages of the source language into the target language. Since translation becomes dynamic, situational, and transformational rather than static and binary, the final decision, in the end, was authorized by the respective translator, and these decisions represent translators' attempt to achieve the closest equivalent possible, but not the absolute equivalence. We believe this study also verifies the theories of Nida \& Taber (1974), Wills (1982), Nababan (2008). The findings of the descriptive-qualitative phase showed that some decisions, such as using such orientation or ideology, finding synonymous meanings, and using loan words, were used as part of negotiation.

As translations are not done in a void, we have also found that the significant time gap between the two translations (around ten years) becomes the primary cause of different translation decisions. TT1 has shown the tendency to use superordinate lexical when encountering cultural terms that did not exist in the target culture. At the same time, TT2 opts for the use of loan words when encountering the same issue. Eventually, we can also conclude that time differences have led to cultural shifts that influence the negotiation process of translators from different generations. These strategies have resulted in loss and gain of information on the target text.

However, we must admit that the findings explored in this study are only limited to the analysis of translation decisions without including the final implications and judgments on information loss, gain, and skewing of information. This research is open, dynamic and transformational. Therefore, a follow-up or further study that analyses translation strategies' impact on the information loss, gain, and skewing is required.

\section{Acknowledgements}

We would like to express our gratefulness to our lecturer, Dr. Sajarwa, M.Hum., who guided us by introducing a lot of translation theories and their development, showed us much literature and encouraged us never to stop reading or writing, learning and exploring many things. 


\section{References}

A Guide to Currency in The UK / Visit Britain. (2021). Retrieved November 8, 2021, from https://www.visitbritain.com/ae/en/plan-your-trip/money/currency-uk.

Aich, Y. (2021). Translation as a reconstructing factor of public relations. International JLLT: Journal of Linguistics, Literature and Translation, 3(8), 81-84. https://doi.org/10.32996/ijllt.2021.4.8.12.

Baker, M. (2018). In Other Words: A Coursebook on Translation (3 ed.). London and New York: Routledge.

Bassnett, S. (2002). Translation Studies. London and New York: Routledge.

Bedeker, L. \& Feinauer, I. (2006). The translator as cultural mediator. Southern African Linguistics and Applied Language Studies, 24 (2), pp. 1-9.

Bester, J. (1991). The other art of the possible. Japan Quarterly, 73- 83. Tokyo: Asahi Shimbun.

Burnett, F. (2010). The Secret Garden: Taman Rahasia (3 ed.). Jakarta: Gramedia Pustaka Utama.

Burnett, F. (2019). The Secret Garden (2 ed.). Jakarta: Gramedia Pustaka Utama.

Burnett, F. (2020). The Secret Garden. Jakarta: PT. Elex Media Komputindo.

Catford, J. (1965). A Linguistic Theory of Translation. London: Oxford University Press.

Cent/ Definition of Cent by Merriam-Webster. (2021). Retrieved November 8, 2021, from https://www.merriam-webster.com/dictionary/cent.

Cronin, M (2003). Translation and Globalization. London and New York: Routledge.

Dow, G. (2007). Translators, Interpretations, Mediators. Switzerland: Peter Lang.

Eco, U. (2003). Mouse or Rats? Translation as Negotiation. Great Britain: Phoenix.

fjord/ National Geographic Society. (2011). Retrieved November 8, 2021, from https://www.nationalgeographic.org/encyclopedia/fjord/.

Foods of England - Dorset Dough Cake. (2015). Retrieved November 8, 2021, from http://www.foodsofengland.co.uk/dorsetdoughcake.html.

Hatim, B. \& Mason, I. (1990). Discourse and the Translator. London and New York: Longman.

Hatim, B. \& Mason, I. (2005). The Translator as Communicator. London and New York: Routledge.

Hirako, Y. (1999). Principles of Translation. Tokyo: Taishuukan Shoten.

Hoed, B. (2006). Penerjemahan dan Kebudayaan. Jakarta: Pustaka Jaya.

House, J. (2018). Translation: The Basics. London and New York: Routledge.

Junus, U. (1985). Resepsi Sastra: Sebuah Pengantar. Jakarta: Gramedia.

McGill School of Computer Science. (2021). Retrieved November 8, 2021, from https://www.cs.mcgill.ca/.

Nababan, M. (2008). Equivalence in translation: some problems-solving strategies. ProZ.com Translation Article Knowledgebase. Retrieved from http://www.proz.com/doc/2071.

Newmark, P. (1988). A Textbook of Translation. China: Shanghai Foreign Language Education Press.

Nida, E., \& Taber, C. (1969). The Theory and Practice of Translation. Leiden: E.J. Brill.

Nida, E., \& Taber, C. (1974). The Theory and Practice of Translation. Leiden: E.J. Brill.

Purnomo, M. \& Baharuddin. (2018). The specific cultural terms and expressions in the translation of literary work (novel). E3S Web Conf., 73. https://doi.org/10.1051/e3sconf/20187314022. 
Translators as Mediator: Cultural Negotiation in Translating English Literary Text into Indonesian, Nadia Khumairo Ma'shumah, Aulia Addinillah Arum, Arif Nur Syamsi

Redelinghuys, C. J. N. (2019). Negotiating an eco-conscious translation of the hebrew bible: Jonah 3:1-10 as test case. Old Testament Essays, 32(3). https://doi.org/10.17159/2312-3621/2019/v32n3a4.

Sajarwa, (2017). Deconstructing Equivalence in the Translation of Texts from French to Indonesian. HUMANIORA, 29(2), 159-168. https://doi.orf/10.22146/jh.24063.

Saule, B. \& Aisulu, N., (2014). Problems of translation theory and practice: original and translated text equivalence. Procedia: Social and Behavioral Sciences, 136, 119-123.

Siponkonski, N. (2014). Translation under Negotiation: The Textual Interplay of Translators and Editors in Contemporary Finnish Shakespeare Translation. Finlandia: University of Vaasa.

Stout definition and meaning / Collins English Dictionary. (2021). Retrieved November 8, 2021, from https://www.collinsdictionary.com/dictionary/english/stout.

stout_1 adjective - Definition, pictures, pronunciation and usage notes / Oxford Advanced American Dictionary at OxfordLearnersDictionaries.com. (2021). Retrieved November 8 , 2021, from https://www.oxfordlearnersdictionaries.com/definition/american_english/stout_1.

Tuppence / Definition of Tuppence by Merriam-Webster. (2021). Retrieved November 8, 2021, from https://www.merriam-webster.com/dictionary/tuppence.

Vanderstoep, S. \& Johnston, D. (2009). Research Methods for Everyday Life: Blending Qualitative and Quantitative Approaches. San Francisco: Jossey-Bass A Wiley Imprint.

Wills, W. (1982). The Science of Translation. Stuttgart: Gunter Narr Verlag Tubingen. 